\title{
Electrolysis of low-temperature suspensions: an update
}

\author{
Andrey Yasinskiy ${ }^{1}$, Andrey Suzdaltsev ${ }^{2}, *$, Sai Krishna Padamata ${ }^{1}$, \\ Petr Polyakov ${ }^{1}$, and Yuriy Zaikov ${ }^{2}$
}

\author{
${ }^{1}$ School of Non-Ferrous Metals and Materials Science, Siberian Federal University, Krasnoyarsk, \\ Russia \\ ${ }^{2}$ Institute of High-Temperature Electrochemistry UB RAS, Yekaterinburg, Russia \\ *suzdaltsev_av@mail.ru
}

\begin{abstract}
Among different "novel" technologies for eco-friendly aluminium production with zero greenhouse gas emissions, the electrolysis of alumina suspension (or slurry) based on halide melts deserves more attention than it got recently. The original idea of the slurry was first proposed by Theodor R. Beck and has been modified and developed basically by Petr V. Polyakov. This paper presents a comprehensive analysis of the current status of this technology, future opportunities, and the new experimental results, which have not been published yet. This overview covers the properties of high-temperature suspensions, including sedimentation behaviour and apparent electrical conductivity; anodic process on oxygen-evolving electrodes, including the polarization characteristics and the bubble behaviour at vertical anodes; cathodic process on wettable substrates; primary electrolysis results; and the general considerations touching upon the possible cell designs and the thermal balance. The future scope of the technology and possible applications are discussed.
\end{abstract}

Keywords: alumina suspension, slurry, low-temperature melts, electrode processes, bubble dynamics, sedimentation, inert anodes

\section{Introduction}

The $\mathrm{CO}_{2}$-free aluminium reduction technology creation is considered as one of the hardest challenges in aluminium industry up to date. It is known that:

○ high alumina concentration in the bath should be maintained to prevent catastrophic corrosion of the anode;

o the solubility of oxides in cryolite melts is decreased with an increase in alumina concentration;

- oxide layer dissolution products are transferred towards the cathode metal mostly by the convection and then are easily reduced by dissolved aluminium in catholyte.

The use of suspension as an electrolyte rather than undersaturated melt can solve the problem of maintaining the melt saturated with oxygen alumina. The suspension also protects produced aluminium from the contamination by slowing down the transfer of anode corrosion products to the cathode.

The method of electrolytic production of aluminium from oxide-halide melts containing dispersed alumina $\left(\mathrm{Al}_{2} \mathrm{O}_{3}\right)$ was first patented by T.R. Beck in 1986 [1]. The systems $\mathrm{BaCl}_{2}-\mathrm{AlF}_{3}-\mathrm{NaF}-\mathrm{NaCl}$ and $\mathrm{BaCl}_{2}-\mathrm{AlF}_{3}-\mathrm{CaF}_{2}-\mathrm{BaF}_{2}-\mathrm{MgF}_{2}$ with a density higher than the density of aluminium and lower than the density of alumina at $700-800{ }^{\circ} \mathrm{C}$ were proposed as an electrolyte. Both factors: the low temperature and the melt density make it possible to use inert electrode materials [2-5] and new effective cell designs. According to Beck, oxygen bubbles are evolved during electrolysis at the anode located at the cell bottom and maintain alumina slurry. Cathodic product (Al) is accumulated on the surface of the melt and periodically removed from the cell.

After the laboratory and pilot industrial electrolysis tests, the $\mathrm{NaF}-\mathrm{AlF}_{3}$ and $\mathrm{KF}-\mathrm{LiF}-\mathrm{AlF}_{3}$ melts with a liquidus temperature of less than $700{ }^{\circ} \mathrm{C}$ were chosen [6-9]. Despite the prospects and obvious relevance of the development of new energy-efficient methods for aluminium production [10-13], the proposed method has not been implemented yet. 
Interest in the electrolytic production of aluminium from high-temperature alumina suspensions based on fluoride and chloride melts of a wide composition in the temperature range from 700 to $965{ }^{\circ} \mathrm{C}$ was renewed by Polyakov et al. [14, 15]. According to the results of a series of electrolysis tests in suspensions, the stability of the anodic and cathodic processes was shown at current densities not higher than $0.2 \mathrm{~A} \mathrm{~cm}^{-2}$ with a cathodic current efficiency (CE) more than $90 \%$. Later, the authors focused on a deeper study of the processes during the electrolysis of alumina suspension in the low-temperature $\mathrm{KF}-\mathrm{AlF}_{3}$ systems [16].

In this paper, we consolidate the available data regarding the properties, electrochemical characteristics, and the behaviour of alumina suspensions in these systems, and also present new experimental results. This information seems to be necessary for the selection of the cell design and the optimal electrolysis parameters.

\section{Properties of $\mathrm{KF}-\mathrm{AlF}_{3}-\mathrm{Al}_{2} \mathrm{O}_{3}$ suspensions}

Due to the low liquidus temperatures and the relatively high solubility of $\mathrm{Al}_{2} \mathrm{O}_{3}$ the $\mathrm{KF}-\mathrm{AlF}_{3}-$ based melts are the promising media for the alumina suspensions electrolysis with oxygenevolving anodes and aluminium-wetted cathodes [17-22]. Since the suspension provides the saturated concentration of the electroactive component in the anode layer, the main criteria for the effectiveness and stability of the suspension electrolysis are the dissolution rate of $\mathrm{Al}_{2} \mathrm{O}_{3}$, the electrical conductivity of the suspensions, and the sedimentation stability (and velocity) of alumina particles in suspension. In terms of dissolution rate, $\gamma-\mathrm{Al}_{2} \mathrm{O}_{3}$ with a large specific surface area seems to be the best for use. On the other hand, such particles can form agglomerates and settle faster on the bottom. We suppose that the behaviour of various grades of alumina upon dissolution in the $\mathrm{KF}-\mathrm{AlF}_{3}$-based melts are similar to their behaviour in molten cryolite [23-25]. The only favourable difference is that the transition of the $\gamma$-phase to the $\alpha$-phase at $700-800{ }^{\circ} \mathrm{C}$ will be significantly inhibited.

The suspension properties should provide the synchronization of the alumina flows as follows:

$\square \quad$ feeding flow, which is easily controllable by an operator;

$\square$ sedimentation flow, which is desired to be as low as possible;

$\square$ dissolution flow, which is the complicated function of the suspension composition, alumina properties and the temperature;

$\square$ dissolved alumina consumption flow, which occurs at anode-suspension interface and can be controlled both by the operator and a cell designer as well.

2.1 Sedimentation of $\mathrm{Al}_{2} \mathrm{O}_{3}$. The velocity $\mathrm{U}_{\mathrm{sp}}$ of the single particle in the liquid is described by the Stokes equation:

$$
U_{s p}=\frac{2}{9} \cdot \frac{a_{p}^{2} \cdot g \cdot\left(\rho_{s}-\rho_{l}\right)}{\eta}
$$

where $a_{p}$ is the particle radius, $g$ is the gravity acceleration, $\rho$ is the density (subindexes $s$ and 1 denote solid and liquid), $\eta$ is the dynamic viscosity. The collective (or batch) sedimentation velocity $\mathrm{U}_{\mathrm{c}}$ is complicated by the $\mathrm{k}(\varphi)$ coefficient, which depends on the particles and medium properties and the suspension composition (and particles volume fraction $\varphi$ ):

$$
U_{c}=\frac{1-\varphi}{k(\varphi)}
$$

The distribution of smelter grade alumina (SGA) solid particles vs. the height of the suspension in the crucible is shown in Fig. 1. 


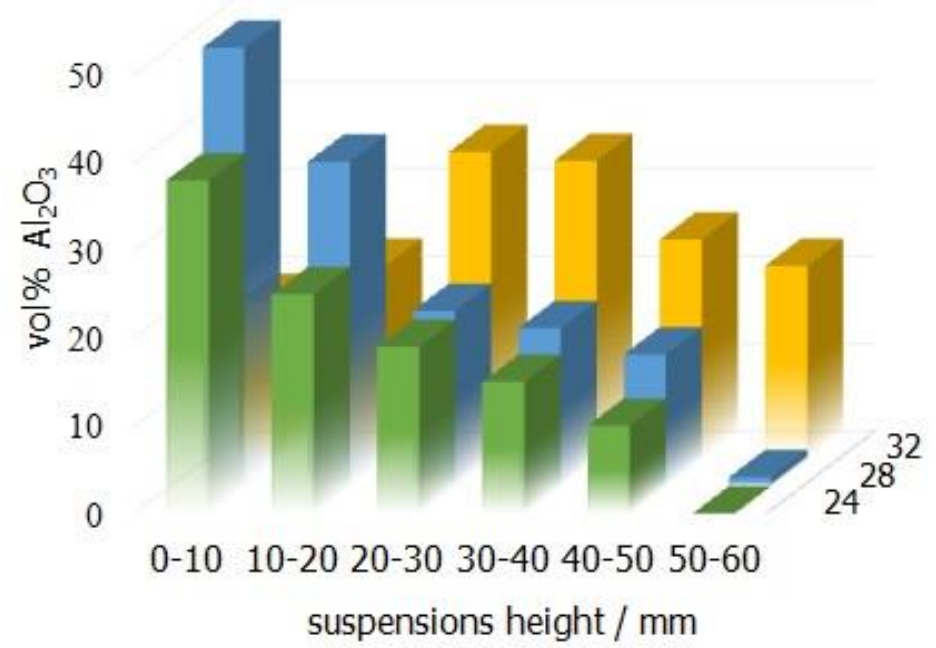

Fig. 1. The distribution of the alumina particles over the height of suspensions with 24,28 , and $32 \mathrm{vol} \%$ of solid $\mathrm{Al}_{2} \mathrm{O}_{3}$ after 15 minutes of sedimentation in $\left(1.3 \mathrm{KF}-\mathrm{AlF}_{3}\right)-\mathrm{Al}_{2} \mathrm{O}_{3}$ melt at $700{ }^{\circ} \mathrm{C}$

[26]

It was shown that with an increase in the volume fraction $\varphi$ in the $\mathrm{KF}-\mathrm{AlF}_{3}-\mathrm{Al}_{2} \mathrm{O}_{3}$ suspension at $700{ }^{\circ} \mathrm{C}$, the sedimentation velocity decreases and becomes close to zero at $32 \mathrm{vol} \%$, which is considered as maximum packing fraction. A decrease in the alumina average particle size and the temperature also leads to a decrease in the sedimentation velocity.

The Stokesian nature of sedimentation was indicated by the Reynolds number $(\mathrm{Re}=0.006 \ldots 0.022)$, which is considered to be the important hydrodynamic parameter and can be calculated according to the equation:

$$
R e=\frac{\rho_{l} \cdot U_{c} \cdot d_{p}}{\eta}=\frac{\rho_{l} \cdot Q \cdot d_{p}}{\eta \cdot S}
$$

where $d_{p}$ is the average particle diameter, $Q$ is the volumetric flow rate, $S$ is the crucible crosssection area.

The uniformity of the average alumina particles size spatial distribution $\nabla d_{p}=f(\tau)$ was evaluated in [27]. Fig. 2 shows the dependences of the average alumina particle size distribution vs. their location in the crucible (coordinates) after 15 minutes sedimentation and a typical micro photo of the suspension.
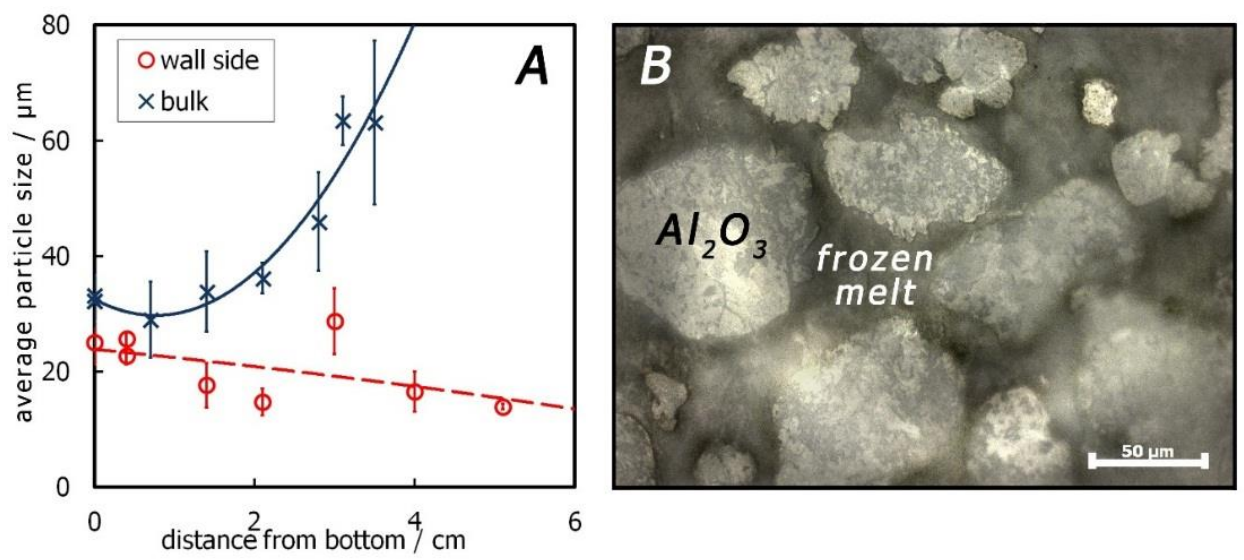

Fig. 2. Distribution of the average particle size of alumina in frozen suspension based on the KF$\mathrm{AlF}_{3}-\mathrm{Al}_{2} \mathrm{O}_{3}$ system with $24 \mathrm{vol} \%$ of solid alumina particles at $700{ }^{\circ} \mathrm{C}(\boldsymbol{A})$ and the typical photo of frozen suspension $(\boldsymbol{B})$ 
It is seen that in the middle of the suspension bulk (30 $\mathrm{mm}$ from the wall), sedimentation occurs less uniformly $\left(\partial \mathrm{d}_{\mathrm{p}} / \partial z \gg 0\right.$ where $\mathrm{z}$ is the distance from the bottom), while near the crucible wall $\mathrm{d}_{\mathrm{p}}$ slightly depends on $\mathrm{z}$ according to the linear law. Apparently, this is due to surface phenomena at the boundaries melt-wall-solid particles, which leads to an increase in the local viscosity of the suspension, high resistance to the dispersion medium layered shear relative to the wall, and stability of the suspension. Thus, the suspension stability will be contributed by a decrease in the interelectrode distance. According to Fig. 2B the particles are separated from each other with a thin layer $(5-50 \mu \mathrm{m})$ of electrolyte.

In the present work, the sedimentation velocity of alumina with different particle size distribution depending on $\varphi$ was also estimated by dynamically measuring the ohmic resistance of the suspension in a volume placed between flat vertical parallel electrodes. The relative change in resistance was used to evaluate the sedimentation of alumina particles in suspensions with different alumina volume fractions. Typical results are shown in Fig. 3.

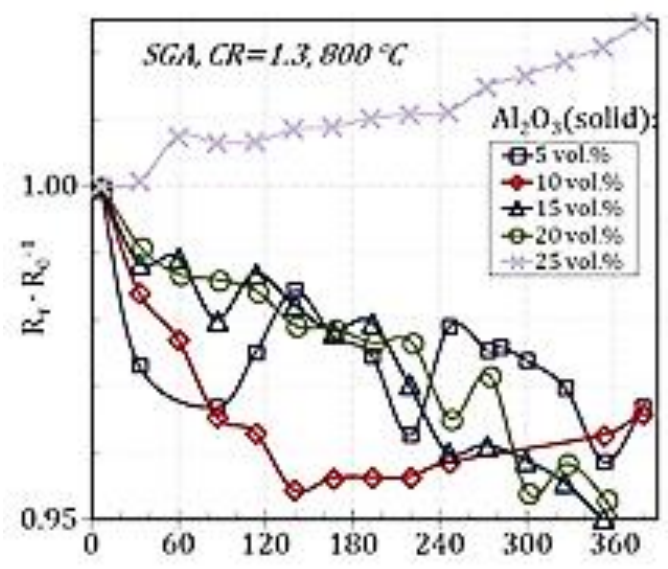

Fig. 3. Dependence of normalized ohmic resistance vs. time for sedimentation of SGA in $\left(1.3 \mathrm{KF}-\mathrm{AlF}_{3}\right)-\mathrm{Al}_{2} \mathrm{O}_{3}$ (sat) suspension at $800{ }^{\circ} \mathrm{C}$

The change in normalized resistance was associated with the change in local $\varphi$. The sedimentation velocity can be estimated with the $\partial\left(R_{\tau} \cdot R_{0}{ }^{-1}\right) / \partial \tau$ value. It can be seen that, in general, the results are comparable with those presented above: a decrease in the sedimentation velocity is facilitated by an increase in particles volume fraction in suspension and a decrease in their average size. Typical sedimentation velocities were in the range of $0.8-3.1 \mathrm{~cm} / \mathrm{s}, \mathrm{k}(\varphi)$ function in the range of 0.024-0.038. Mechanical activation of alumina enhanced sedimentation stability and can allow performing sustainable electrolysis with low alumina volume fractions (0.10-0.15). More details will be presented in further publications.

2.2 Apparent electrical conductivity. The presence of $\mathrm{Al}_{2} \mathrm{O}_{3}$ particles increases the resistance of the electrolyte by reducing its specific volume and the cross-section area for the charge transfer. Fig. 4 shows the primary results of the experimental apparent electrical conductivity measurement of the alumina suspensions based on the $\left(1.3 \mathrm{KF}-\mathrm{AlF}_{3}\right)-\mathrm{Al}_{2} \mathrm{O}_{3}$ melt at $700{ }^{\circ} \mathrm{C}$. 


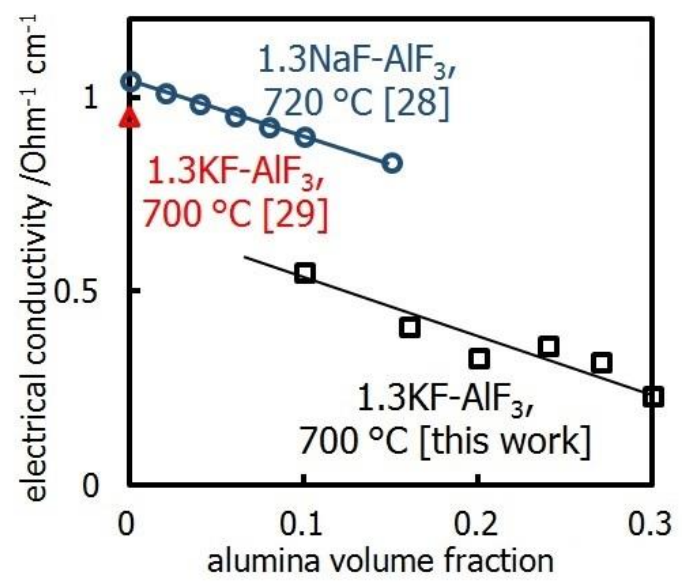

Fig. 4. The dependence of the electrical conductivity of the oxide-fluoride melts $(\varphi=0)$ and alumina suspensions at $700-720^{\circ} \mathrm{C}$

The solid phase fraction increase logically reduces the apparent electrical conductivity of the system. Comparative analysis (Fig. 4) shows the conductivity of an $\mathrm{Al}_{2} \mathrm{O}_{3}$-saturated $1.3 \mathrm{KF}-\mathrm{AlF}_{3}$ melt [29] and the calculated values of the electrical conductivity of the $\left(1.3 \mathrm{NaF}-\mathrm{AlF}_{3}\right)-\mathrm{CaF}-\mathrm{Al}_{2} \mathrm{O}_{3}$ melt at $720{ }^{\circ} \mathrm{C}$ [28]. It can be seen that from the electrical conductivity point of view, a system based on $\mathrm{NaF}-\mathrm{AlF}_{3}-\mathrm{Al}_{2} \mathrm{O}_{3}$ looks preferable for the suspension electrolysis. We assume that the current densities of aluminium and oxygen evolution will be several times lower than those of traditional cells. In this case, a decrease in the electrical conductivity of the system can even be positive in terms of heating the suspension to operating temperature.

2.3 Density, viscosity and surface tension. In addition to the electrical conductivity, properties such as density, apparent viscosity and apparent surface tension of suspensions are important in terms of the suspension stability and removal of electrolysis products from the interelectrode space. At present, only the data on the corresponding molten systems $\mathrm{KF}-\mathrm{AlF}_{3}-\mathrm{Al}_{2} \mathrm{O}_{3}$ and $\mathrm{NaF}-$ $\mathrm{AlF}_{3}-\mathrm{Al}_{2} \mathrm{O}_{3}$ [16-20, 30-32], which are summarized in Table 1, are present in the literature.

Table 1. Comparison of the basic physicochemical properties of electrolytes for the preparation of alumina suspensions [16-20, 30-32]

\begin{tabular}{lcc}
\hline \multicolumn{1}{c}{ Melt / Property } & $\mathrm{KF}-\mathrm{AlF}_{3}$ & $\mathrm{NaF}-\mathrm{AlF}_{3}$ \\
\hline$[\mathrm{MF}] /\left[\mathrm{AlF}_{3}\right]$ ratio, mol mol & \\
Liquidus temperature, ${ }^{\circ} \mathrm{C}$ & 1.22 & 1.3 \\
$\mathrm{Al}_{2} \mathrm{O}_{3}$ solubility, wt $\%$ & 575 & $715-720$ \\
Density at $750^{\circ} \mathrm{C}, \mathrm{kg} \mathrm{m}^{-3}$ & 4.5 at $700{ }^{\circ} \mathrm{C}$ & 1.2 at $702{ }^{\circ} \mathrm{C}$ \\
Kinematic viscosity, ${ }^{2} \mathrm{~s}^{-1}$ & 1770 & 1910 \\
Dynamic viscosity, $\mathrm{mPa} \mathrm{s}^{\circ}$ & $1.53 \times 10^{-6}$ & $0.72 \times 10^{-6}$ \\
Surface tension at $750{ }^{\circ} \mathrm{C}, \mathrm{mN} \mathrm{m}^{-1}$ & 2.71 & 1.38 \\
Interfacial tension at $750{ }^{\circ} \mathrm{C}^{-6} \mathrm{~m} \mathrm{~m}^{-1}$ & 138 & 89 \\
Electrical conductivity, $\mathrm{Ohm}^{-1} \mathrm{~cm}^{-1}$ & $701 \pm 10$ & $796 \pm 5$ \\
\hline
\end{tabular}

It can be assumed that a change in these properties upon introducing $\mathrm{Al}_{2} \mathrm{O}_{3}$ particles into these melts will be determined by their properties, as in the case with a change in their electrical conductivity.

\section{Electrode processes in $\mathrm{KF}-\mathrm{AlF}_{3}-\mathrm{Al}_{2} \mathrm{O}_{3}$ melts and suspensions}

Design of a novel electrochemical technology makes the electrode processes being of primary interest because they affect the electrolysis sustainability, the major indicators (energy consumption, CE, cathodic metal purity) and determine the operating parameters.

3.1 Anodic process. The anodic processes on glassy carbon and platinum, as well as degradation processes on oxygen-evolving anodes in low-melting $\mathrm{NaF}-\mathrm{AlF}_{3}-\mathrm{Al}_{2} \mathrm{O}_{3}$ and $\mathrm{KF}-\mathrm{AlF}_{3}-\mathrm{Al}_{2} \mathrm{O}_{3}$ 
systems are discussed in [2-5, 34-38]. On the basis of resource tests, it was shown that lowering the temperature to $750-800{ }^{\circ} \mathrm{C}$ favourably affects the corrosion resistance of oxygen-evolving anodes, and the study of the anodic process on them seems relevant.

The experiments and theoretical modelling of the process on platinum anodes during the electrolysis of the $\mathrm{KF}-\mathrm{AlF}_{3}-\mathrm{Al}_{2} \mathrm{O}_{3}$ melts are presented in $[35,36]$. Fig. 5 shows typical currentvoltage dependences obtained under argon and oxygen atmosphere at different temperatures. During anodic polarization of platinum, a peak appears on voltammograms, after which the evolution of gaseous oxygen starts. Moreover, even with a slight increase in temperature, the peak in the voltammograms is not recorded, which may indicate a change in the stability of the intermediate products of the anode process. Based on the results of a comparative analysis of experimental data and theoretical calculations, it was concluded that the process under study includes the stage of formation of an intermediate oxide compound on the surface of platinum with its subsequent physical and electrochemical decomposition [35]. In stationary mode the limiting current of oxygen evolution on platinum reaches $2 \mathrm{~A} \mathrm{~cm}^{-2}[36]$ in the $\mathrm{KF}-\mathrm{NaF}-\mathrm{AlF}_{3}-\mathrm{Al}_{2} \mathrm{O}_{3}$ melt $\left(([\mathrm{KF}]+[\mathrm{NaF}]) /\left[\mathrm{AlF}_{3}\right]=1.3 \mathrm{~mol} \mathrm{~mol}^{-1}\right)$ at $780{ }^{\circ} \mathrm{C}$.

$\mathrm{Pt}$ is known to be a proper model electrode for the study of the mechanisms and kinetics of oxygen evolution; however, it obviously cannot be applied in the industry due to economic reasons. $\mathrm{Cu}-$ based alloys have been considered as promising candidates for inert anodes. The effect of alumina particles in the melt on the kinetic parameters of the process at the $\mathrm{Cu}-\mathrm{Al}$ oxygen-evolving anode is shown in Fig. 6.
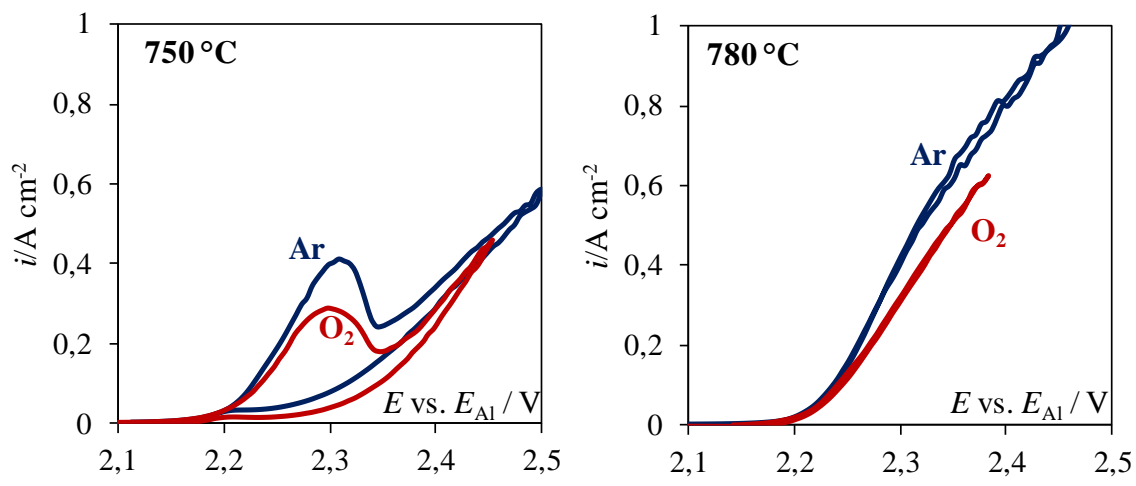

Fig. 5. Voltammograms recorded on platinum in the saturated $1.3(\mathrm{KF}-\mathrm{NaF})-\mathrm{AlF}_{3}-\mathrm{Al}_{2} \mathrm{O}_{3}$ melt under argon (Ar) and oxygen $\left(\mathrm{O}_{2}\right)$ atmosphere at 750 and $780{ }^{\circ} \mathrm{C}$ (sweep rate $-0.1 \mathrm{~V} \mathrm{~s}^{-1}$ ) [36]

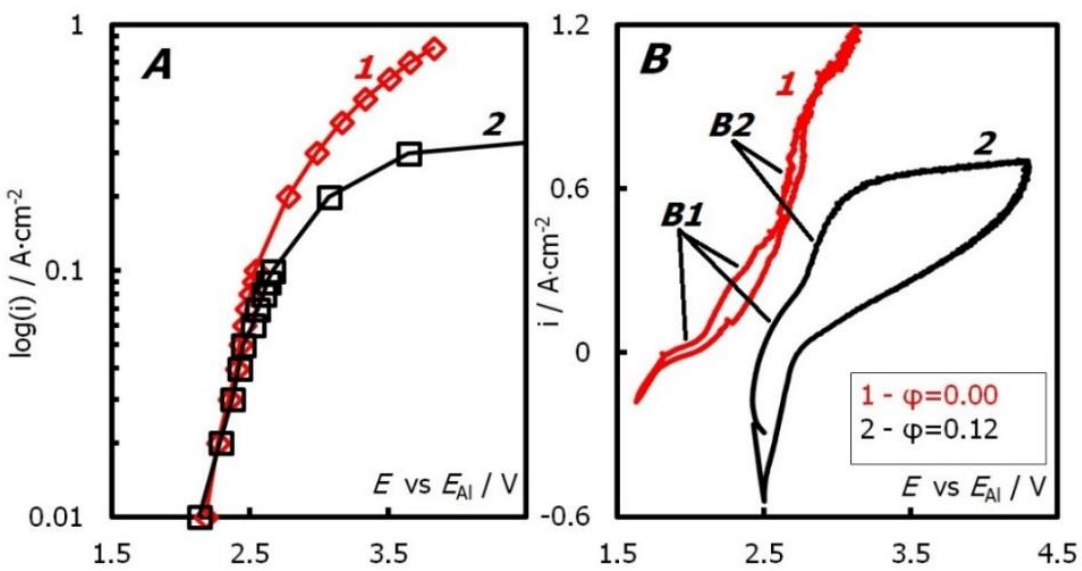

Fig. 6. Stationary polarization dependences (A) and voltammograms (B) obtained on a $\mathrm{Cu}-\mathrm{Al}$ alloy in the saturated $\left(1.3 \mathrm{KF}-\mathrm{AlF}_{3}\right)-\mathrm{Al}_{2} \mathrm{O}_{3}$ melt and suspension at $750{ }^{\circ} \mathrm{C}$ (sweep rate $-0.05 \mathrm{~V} \mathrm{~s}$ 1)

Under the stationary and non-stationary polarization, the oxygen evolution currents are consistent with the results obtained for platinum. The non-stationary polarization of the $\mathrm{Cu}-\mathrm{Al}$ anode leads to the appearance of the anode components oxidation section $(\boldsymbol{B} 1)$ on the voltammogram before 
oxygen evolution (B2). The introduction $\alpha-\mathrm{Al}_{2} \mathrm{O}_{3}$ particles $(\varphi=0.12)$ into the melt leads to a $1.5-$ 2 -fold decrease in the oxygen evolution currents, which can be explained by a screening of the anode surface with alumina particles and bubbles, and by the appearance of additional difficulties in the desorption of oxygen bubbles [39]. More details on the anodic process at $\mathrm{Cu}-\mathrm{Al}$-based electrodes can be found in the article published in the current issue [40].

3.2 Gas evolution regularities. Oxygen is believed to be the major anodic product during sustainable electrolysis with inert anodes in oxide-fluoride melts and suspensions. Oxygen bubbles are generated from the saturated liquid on the preferable nucleation sites and growth by absorption of dissolved gas and coalescence.

Based on the results of electrolysis tests in suspension [41], gas evolution in an $\mathrm{H}_{2} \mathrm{SO}_{4}$ suspension with properties close to that of the suspensions studied and model calculations [42], a motion scheme and patterns of anode gas bubbles formed on an oxygen-evolving electrode as a result of suspension electrolysis were demonstrated. The interfacial tension of the melt is almost 2 times higher than that of an aqueous solution, which will affect the interfacial energies at the electrodegas-electrolyte boundaries. We assume that the presence of alumina solid particles levels the influence of surface energy and the viscosity and density of suspensions become the main criteria for the dynamics of bubble growth. Two different kinds of bubbles could be observed at the same time (Fig. 7): the slugs (9) and the small bubbles. The slugs move through the channel $(\mathbf{2}, \mathbf{5}, \mathbf{6})$ with less density than that of the other layers. The channel is formed by the slugs itself through the particles transport to the top layer $(\mathbf{1}, \mathbf{2}, \mathbf{3})$ where the small bubbles and the particles are accumulated. After the bubble is grown in anodic liquid (less dense) layer (4) and detached from the surface it moves down due to the electrolyte backflow till it coalesces with the slug or other small bubbles or enters the interslug three-phase layer (6). Movement of the slugs transmits the motion to the moving two-phase layer (7), which stays bubble-free while another two-phase layer (8) remains motionless. An increase in the alumina fraction in the suspension enhances the hydrodynamic resistance and complicates the convective transfer of anode gases, increases the electrical resistivity due to an increase in the volume of the non-conducting phase (gas bubbles and alumina particles).

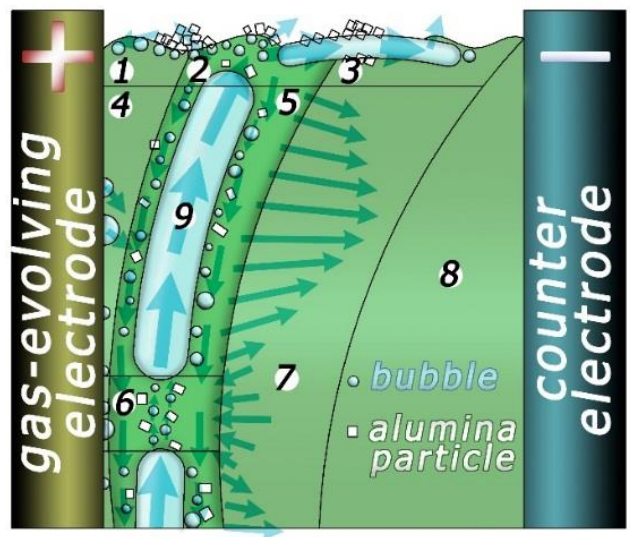

Fig. 7. Scheme of movement (arrows) of bubbles, alumina particles and electrolyte volumes in the anodic space of suspension [41]: 1) anode top layer, 2) top part of gas channel, 3) top layer, 4) anodic liquid layer, 5) gas channel, 6) interslug three-phase layer, 7) moving two-phase layer, 8) motionless two-phase layer, 9) slug.

The dependence of the three-phase layer thickness vs. distance from the bottom and the frames of the recorded bubble movement at the gas-evolving electrode obtained on the water model are presented in Fig. 8. The water model was designed for dimensionless similarity criteria: modified Reynolds number $\mathrm{Re}^{*}=16.24$, Galileo number $\mathrm{Ga}=(1.78 \ldots 2.00) \cdot 10^{10}$, Weber number $\mathrm{We}=$ $(5.96 \ldots 9.8) \cdot 10^{10}$, geometrical simplex $\mathrm{h} / \mathrm{l}=7.5 \mathrm{~h}$ and 1 denote the electrode height and interelectrode distance respectively) and $\varphi=0.3$. The alumina suspension based on $20 \% \mathrm{H}_{2} \mathrm{SO}_{4}$ water solution was used as an electrolyte at $50{ }^{\circ} \mathrm{C}$. 

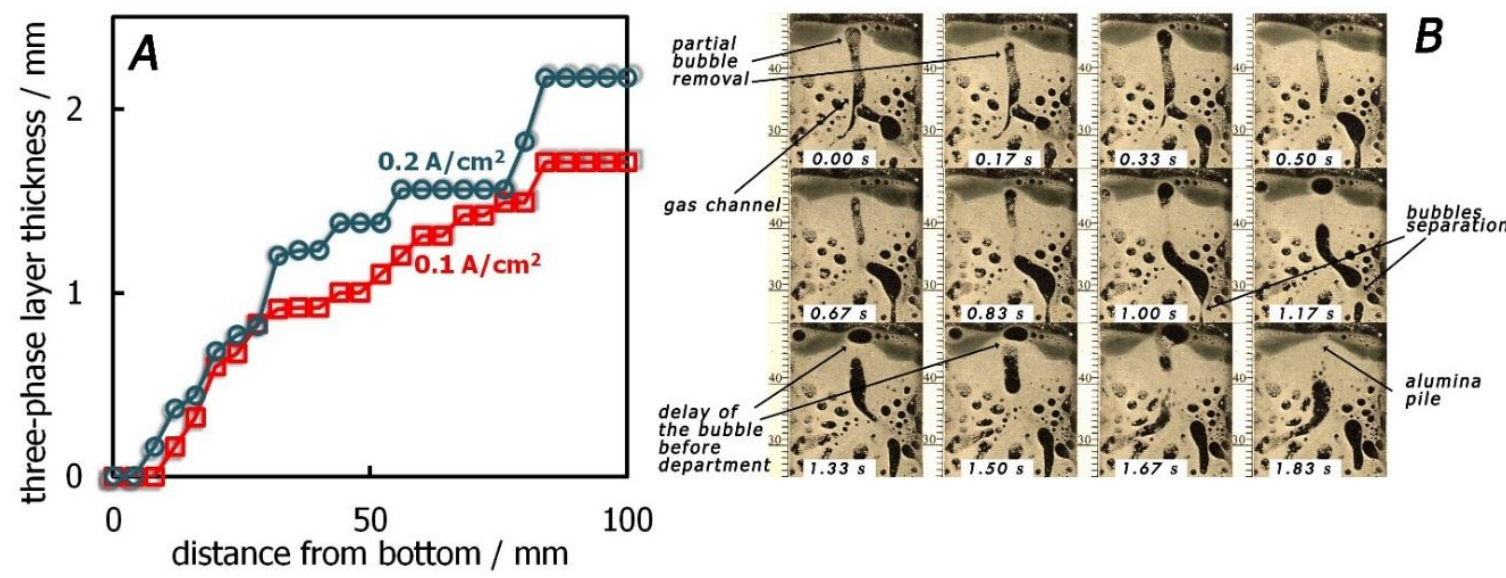

Fig. 8. Dependence between the three-phase layer thickness and the distance from the bottom (height) for anodic evolution of oxygen bubbles in $\mathrm{H}_{2} \mathrm{SO}_{4}$ solution at 0.1 and $0.2 \mathrm{~A} \mathrm{~cm}^{-2}(\boldsymbol{A})$ and the frames with recorded gas evolution $(\boldsymbol{B})$ at $0.05 \mathrm{~A} \mathrm{~cm}^{-2}$

It was shown that due to a decrease in temperature, current density, and the appearance of the hydrodynamic resistance, the velocity of anodic gas bubbles in suspensions decreases by 10 times to be as low as $1.0-2.3 \mathrm{~cm} \mathrm{~s}^{-1}$. The width of the bubbles is comparable $(0.8-2.3 \mathrm{~mm})$ to the one in Hall-Heroult cell [17], however, the length can reach more than $20 \mathrm{~mm}$. Due to the low velocity, increased gas fraction and hydrodynamic resistance, a significant horizontal component of the bubble velocity appears in the direction away from the vertical anode. All this leads to the fact that the main mechanism of the anode gases motion in the suspension becomes to be the slug flow. The observations follow to the conclusion that forced gas removal (through some kind of porous electrode) is highly desirable for the technology.

3.3 Cathodic process. Much attention was paid to the study of cathode polarization in melts and suspensions $[44,45]$. The effect of the temperature $\left(670-800{ }^{\circ} \mathrm{C}\right)$, cathode material (tungsten, glassy carbon), ratio $[\mathrm{KF}] /\left[\mathrm{AlF}_{3}\right]\left(1.3\right.$ and $\left.1.5 \mathrm{~mol} \mathrm{~mol}^{-1}\right), \varphi(0 ; 0.18$ and 0.30$)$ on the kinetic parameters of the aluminium reduction from the $\mathrm{KF}-\mathrm{AlF}_{3}-\mathrm{Al}_{2} \mathrm{O}_{3}$ melts and suspensions were studied both under stationary and non-stationary conditions. Fig. 9 shows typical stationary and non-stationary polarization curves on tungsten.
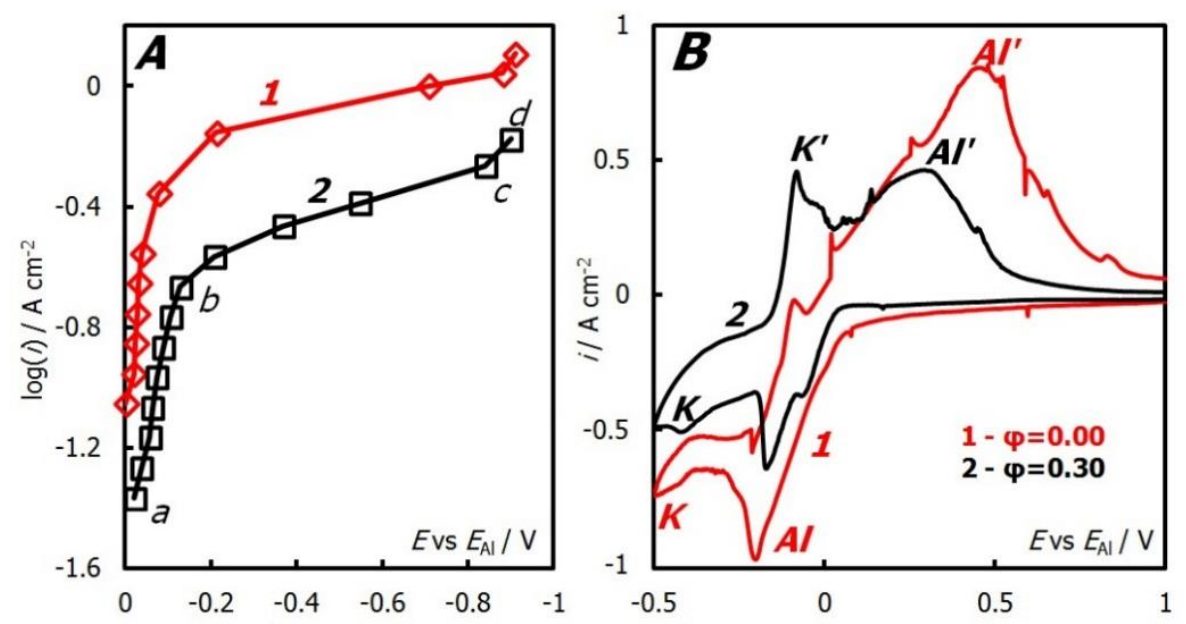

Fig. 9. Stationary polarization curves (A) and voltammograms (B) obtained on tungsten in a saturated $\left(1.3 \mathrm{KF}-\mathrm{AlF}_{3}\right)-\mathrm{Al}_{2} \mathrm{O}_{3}$ melt and suspension at $750{ }^{\circ} \mathrm{C}$ [45].

On the stationary polarization curves (Fig. 9A) aluminium reduction section ( $\boldsymbol{a}$ - $\boldsymbol{b})$ followed by limiting currents of aluminium section $(\boldsymbol{b}-\boldsymbol{c})$ found ranged from 0.15 to $0.70 \mathrm{~A} \mathrm{~cm}^{-2}$ depending on the conditions and then followed by the potassium evolution section $(\boldsymbol{c}-\boldsymbol{d})$. According to nonstationary voltammograms (Fig. 9B) aluminium reduction starts at a potential of about $0 \mathrm{~V}$ relative 
to the aluminium electrode potential with the appearance of a cathode peak $(A l)$ in the potential region of $-0.3 \ldots-0.45 \mathrm{~V}$. With a further potential shift, the negative current of aluminium reduction persists up to the wave of potassium evolution $(\boldsymbol{K})$ at potentials more negative than $-1.1 \mathrm{~V}$. On the anodic part of the curve the peaks of potassium $\left(\boldsymbol{K}^{\prime}\right)$ and aluminium $\left(\boldsymbol{A l} \boldsymbol{l}^{\prime}\right)$ oxidation are observed. Based on these observations, a scheme of the cathodic process in $\mathrm{KF}-\mathrm{AlF}_{3}-\mathrm{Al}_{2} \mathrm{O}_{3}$ melts is proposed, which includes parallel electrochemical stages of the discharge of fluoride and oxidefluoride ions, as well as the probability of partial salt passivation of the cathode and the interaction of reduced aluminium with $\mathrm{KF}$.

Introduction of $\mathrm{Al}_{2} \mathrm{O}_{3}$ particles and increases in its proportion in the suspension increases cathodic overvoltage and decreases the limiting current density of aluminium reduction under stationary conditions for all investigated temperatures and $[\mathrm{KF}] /\left[\mathrm{AlF}_{3}\right]$ ratios.

The using $\mathrm{KF}-\mathrm{AlF}_{3}$ systems widens the electrochemical window for the aluminium electrodeposition without an alkali metal reduction. In $\left(1.3 \mathrm{NaF}-\mathrm{AlF}_{3}\right)-\mathrm{Al}_{2} \mathrm{O}_{3}$ melts at $860{ }^{\circ} \mathrm{C}$ sodium is reduced at a potential $0.2 \ldots 0.25 \mathrm{~V}$ more negative than the aluminium reduction potential $[46,47]$. This can be a significant obstacle to the sustainable electrolysis of the suspension since the recirculation of the cathode layer in suspensions is extremely difficult.

3.4 Electrolysis tests. The longest successful test was performed by Simakov [48] in alumina suspension based on $\mathrm{NaAlF}_{4}-\mathrm{LiF}$ melt with cermet $\mathrm{Cu}_{2} \mathrm{O}-\mathrm{Cu}$ anode and protective graphite cathode at $750{ }^{\circ} \mathrm{C}$ at the cathodic current density of $0.15 \mathrm{~A} \mathrm{~cm}^{-2}$ with $\mathrm{CE}$ of more than $90 \%$ (which is extraordinary high for laboratory cell) and the specific energy consumption of less than 12.8 $\mathrm{kWh} / \mathrm{kg}$ Al. Fig. 10 represents the cell voltage change during electrolysis of melt for 3 hours $(\boldsymbol{A})$, a gradual increase of alumina volume fraction till $\sim 0.24$ for 6 hours $(\boldsymbol{B})$ and electrolysis of suspension for 39 hours $(\boldsymbol{C})$. The cathode had channels for the removal of aluminium from interelectrode space $(\boldsymbol{D})$.

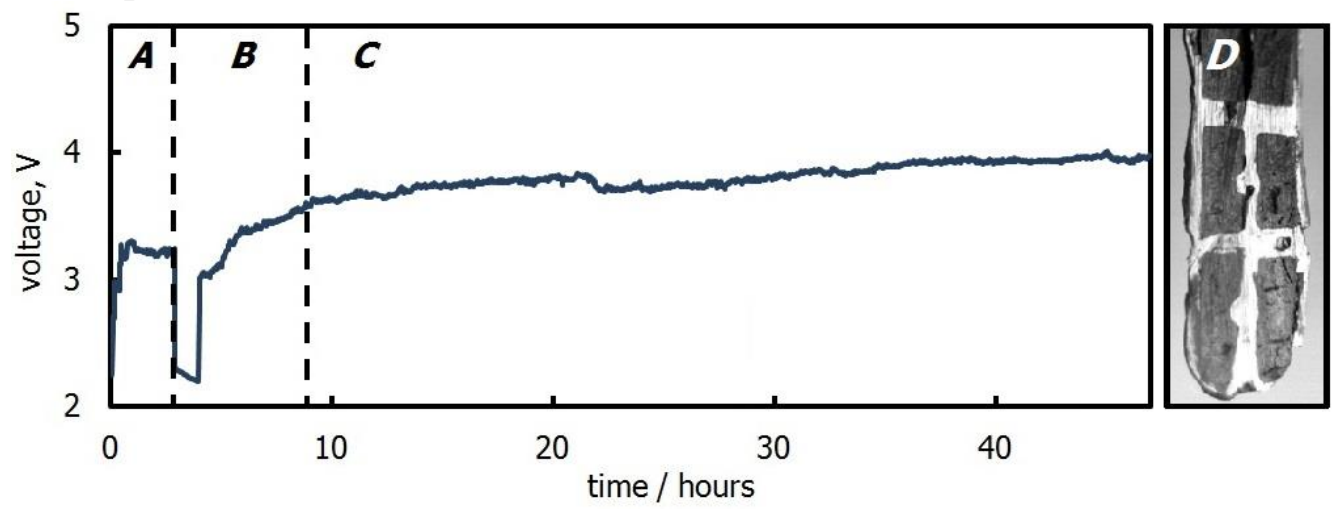

Fig. 10. The voltage vs. time during the electrolysis of melt and suspension (see description in the text)

The voltage slightly increased during the test that was explained by the increase in the contact resistances. However, the highest value was between 3.9 and $4.0 \mathrm{~V}$ which is rather low due to the low current densities resulted in low overvoltages and low voltage drop in the suspension layer, which was $2.5 \mathrm{~cm}$. The channels inside the cathode were filled with aluminium that confirms the possibility to remove aluminium through the electrode body.

The results obtained up to date [45] support the idea of aluminium production in alumina suspension at $750-800{ }^{\circ} \mathrm{C}$ at low current densities of $0.1-0.3 \mathrm{~A} \mathrm{~cm}^{-2}$. Higher values often lead to the anode or cathode passivation, uncontrollable change in cell voltage and temperature. Another phenomenon, which has been observed (mostly for SGA) is Ostwald ripening (or recrystallization) of alumna that forms huge agglomerates of $\alpha-\mathrm{Al}_{2} \mathrm{O}_{3}$. It contributes to the cell voltage increase and makes the operation of the cell difficult. This phenomenon was not observed in suspensions with mechanically activated alumina.

\section{Simulations of suspension behaviour at electrolysis}


All the above results and patterns of alumina suspensions behaviour are necessary for the development of both the cell design and for the technology parameters determination. To increase the efficiency of such developments and to obtain the fastest practically important results, thermal and electrical fields in the cell with vertical bipolar electrodes (20 in a row) were calculated [16]. The model cathodic current density was $0.4 \mathrm{~A} \mathrm{~cm}^{-2}$. It was shown that aluminium can be obtained by electrolysis of alumina suspensions in melts based on the $\mathrm{KF}-\mathrm{AlF}_{3}$ system with productivity of 5-7 kg Al/h with energy consumption of $12.8-13.5 \mathrm{MW} \cdot \mathrm{h} / \mathrm{t} \mathrm{Al}$.

The high temperatures at the surfaces show that artificial cooling or current density reduction may be required for the sustainable process. It is worth to remark that at the time of the modelling [16], many of the data presented in this paper were not available, and the model may require optimization.

\section{Cell designs}

An interesting idea is the development of the commercial cell for the electrolysis of alumina suspensions in oxide-fluoride melts. Mandatory conditions for sustainable cell operation are:

$\square$ electrolysis at permissible current densities (see section 3);

$\square$ electrodes dimensional stability;

$\square \quad$ cathode aluminium and anode gases removal;

$\square \quad$ maintaining alumina suspension physically stable (without local densification).

From the works [7, 15], two basic concepts of the cell are known, which differ in the method of cathode aluminium removal from the electrolysis zone. In the cell concept by Beck [7] prevention of alumina sedimentation is achieved by using an anode with vertical and horizontal gas-evolving surfaces (Fig. 12A). Moreover, the gas evolution under the cathode should contribute to the accumulation of cathode aluminium above the horizontal surface of the anode. However, the release of anode gases under the cathode and aluminium provides significant convection in the interelectrode space, which will not allow separating the electrolysis products, to achieve high $\mathrm{CE}$ and low specific energy consumption.
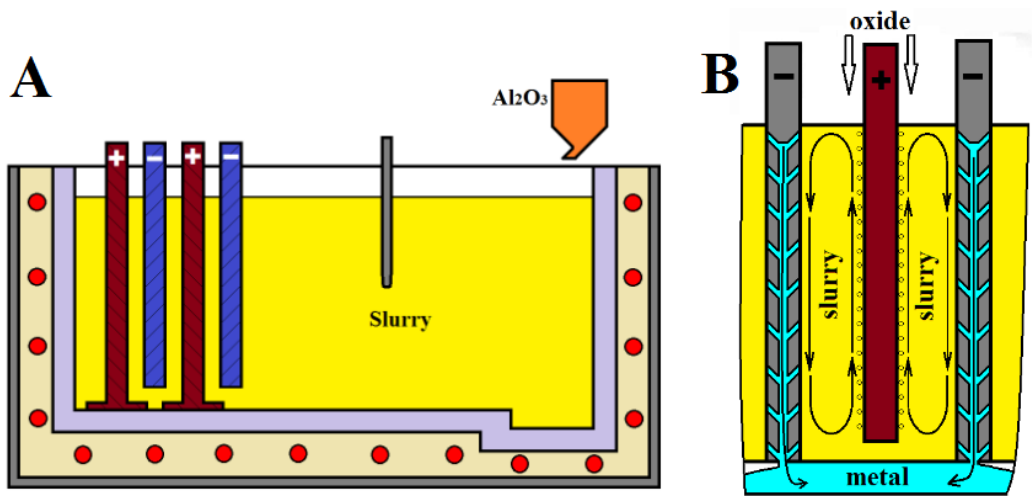

Fig. 11. Schematic representation of the electrode arrangement for alumina suspensions electrolysis: A - Beck [7], B - Polyakov, Simakov [15]

For the removal of liquid metal from the cell Polyakov et al. proposed cathodes with channels (Fig. 11B). During the electrolysis of suspension (6...40 vol.\%) gases released at the anode move the electrolyte up along the anode surface and down along the cathode surface. Additionally, the flow of electrolyte along the surface of the cathodes improves the removal of metal (aluminium) through the channels under the "false" bottom of the cell. In the described concept, the main volume of the suspension in the interelectrode space should not take part in the electrolyte circulation, while it should be in suspension effectively separating the electrolysis products.

Variants of cell designs with inclined bipolar electrodes are also known [12], which, however, seems less promising due to the complexity of their arrangement and maintenance. 
From the above information, we can conclude that there are quite a few options for the cell design for the alumina suspensions electrolysis in the scientific and technical literature, but so far they have not even found laboratory use.

\section{Conclusion}

A significant amount of reproducible data has been obtained in a wide range of experimental conditions to date. Based on the available data, experiments on the alumina suspensions electrolysis in laboratory cells were conducted and the fundamental possibility of aluminium production by this method was shown. The laboratory-scale electrolysis of alumina suspensions in melts based on the $\mathrm{NaF}-\mathrm{KF}-\mathrm{AlF}_{3}$ system was performed with cathodic $\mathrm{CE}>90 \%$ and specific energy consumption of $12.8-13.5 \mathrm{~kW} \cdot \mathrm{h} / \mathrm{kg} \mathrm{Al}$.

The laboratory-scale results displayed that the technology can be operated at the parameters:

$\square \quad$ anodic and cathodic current densities of $0.1-0.3 \mathrm{~A} \mathrm{~cm}^{-2}$;

$\square$ the 10-15 vol.\% alumina with the average particle size less than $10 \mu \mathrm{m}$ (mechanical activation seems to be the promising solution);

$\square \quad$ the 28-32 vol.\% alumina with SGA (can lead to Ostwald ripening);

$\square$ electrolyte composition $1.3(\mathrm{KF}-\mathrm{NaF})-\mathrm{AlF}_{3}+\mathrm{LiF}$ (optional);

$\square$ the temperature of $750-800{ }^{\circ} \mathrm{C}$ (higher current densities naturally require higher temperature);

$\square$ continuous removal of electrolysis products from the interelectrode space through porous electrodes;

$\square \mathrm{Cu}_{90} \mathrm{Al}_{10}$ anode (or other with high corrosion resistance);

$\square \quad$ the wettable cathode $\left(\mathrm{TiB}_{2}-\right.$ based $)$;

$\square \quad$ the interelectrode distance of $1.0-2.5 \mathrm{~cm}$ (higher current densities naturally require higher spaces).

Proper design of the gas-removing electrode and maintaining suspended alumina particles are of high importance. The first one appears to be a challenging problem, whereas the second one can be solved by choosing the proper cell design and the suspension composition, as well as the electrolysis parameters. Mechanical activation seems to be able to provide high resistance towards sedimentation, Ostwald ripening and to increase the dissolution rate.

\section{Acknowledgements}

The reported study was funded by RFBR according to the research project №19-38-50018.

\section{References}

1. Beck Th.R. and Brooks R. (1986) Method and apparatus of electrolytic reduction of alumina, Patent US4592812.

2. Pawlek R.P. (2013) In "Essential readings in light metals: Electrode technology for aluminium production, 4:1126-1133. DOI: 10.1002/9781118647745.ch157.

3. Beck Th.R., MacRae C.M., and Wilson N.C. (2011) Metal anode performance in lowTemperature electrolytes for aluminium production, Met. \& Mat. Trans. B, 42: 807-813.

4. Kovrov V.A., Khramov A.P., Zaikov Yu.P., Nekrasov V.N., and Ananyev M.V. (2011) Studies on the oxidation rate of metallic inert anodes by measuring the oxygen evolved in lowtemperature aluminium electrolysis, J. Appl. Electrochem., 41:1301-1309.

5. DeYoung D.H. (1986) Solubilities of oxides for inert anodes in cryolite-based melts, TMS Light Metals, 1986:299-307.

6. Beck Th.R. and Brooks R. (1989) Electrolytic reduction of alumina, Patent US4865701.

7. Beck Th.R. and Brooks R. (1991) Electrolytic reduction of alumina, Patent US5006209.

8. Beck Th.R. (1994) Production of aluminium with low temperature fluoride melts, TMS Light Metals, 1994:417-423.

9. Beck Th.R. (1995) A non-consumable anode for production of aluminium with lowtemperature fluoride melts, TMS Light Metals, 1995:355-360. 
10. Brown C.W. (2000) Laboratory experiments with low-temperature slurry-electrolyte alumina reduction cells, TMS Light metals, 2000:391-396.

11. Brown C.W. (1998) The wettability of $\mathrm{TiB}_{2}$-based cathodes in low-temperature slurryelectrolyte reduction cells, JOM, 50(5): 38-40.

12. Welch B.J. (1999) Aluminium production paths in the new millennium, JOM, 51(5):24-28.

13. Tabereaux A. (2007) Aluminium industry upgrade set in motion by new wave of high amperage prebakes, Light Metal Age, 2007:28-30.

14. Polyakov P.V., Blinov V.A., Voinich A.L., Simakov D.A., and Gusev A.O. (2008) Electrolysis of thickened alumina slurry as a method of Hall-Heroult process update, J. Siberian Federal University. Engineering \& Technologies, 2008(1):135-154.

15. Polyakov P.V. and Simakov D.A. (2004) Method of production of metals by electrolysis of the molten salts, Patent RU2274680C2.

16. Polyakov P.V., Klyuchantsev A.B., Yasinskiy A.S., and Popov Y.N. (2016) Conception of "Dream Cell" in aluminium electrolysis, TMS Light metals, 2016:283-288.

17. Thonstad J., Fellner P., Haarberg G.M., Hives J., Kvande H., and Sterten A. (2001) Aluminium electrolysis. Fundamentals of the Hall-Heroult process. 3 ed. Dusseldorf, Aluminium-Verlag Marketing \& Kommunikation $\mathrm{GmbH}, 354$ p.

18. Danielik V. (2005) Phase equilibria in the system $\mathrm{KF}-\mathrm{AlF}_{3}-\mathrm{Al}_{2} \mathrm{O}_{3}$, Chemical Papers, 59(2):81-84.

19. Apisarov A., Dedyukhin A., Nikolaeva E., Tinghaev P., Tkacheva O., Redkin A., and Zaikov Y. (2010) Liquidus temperatures of cryolite melts with low cryolite ratio, TMS Light Metals, 2010:395-398.

20. Robert E., Olsen J.E., Danek V., Tixhon E., Ostvold T., and Gilbert B. (1997) Structure and thermodynamics of alkali fluoride-aluminium fluoride-alumina melts. Vapor pressure, solubility, and Raman spectroscopic studies, J. Phys. Chem. B, 101:9447-9457.

21. Apisarov A.P., Dedyukhin A.E., Redkin A.A., Tkacheva O.Yu., and Zaikov Yu.P. (2010) Physicochemical properties of $\mathrm{KF}-\mathrm{NaF}-\mathrm{AlF}_{3}$ molten electrolytes, Rus. J. Electrochem., 46:633-639.

22. Frazer E.J. and Thonstad J. (2010) Alumina solubility and diffusion coefficient of the dissolved alumina species in low-temperature fluoride electrolytes, Met. \& Mat. Trans. B, 41:543-548.

23. Isaeva L.A., Mikhalev Yu.G., Polyakov P.V., and Muratov A.M. (1999) The dissolution rate of alumina with various properties and the temperature responses of the electrolyte, Tsvetnye metally, 1999(10):40-43.

24. Isaeva L.A., Braslavskii A.B., Polyakov P.V. (2009) Effect of the content of the $\alpha$-phase and granulometric composition on the dissolution rate of alumina in cryolite-alumina melts, Rus. J. Non-Ferrous Metals, 50(6):600-605

25. Haverkamp R.G., Welch B.J., and Metson J.B. (1992) Models of alumina dissolution in cryolite, Proc. Electrochemical Society, PV 1992-16:646-659.

26. Yasinskiy A.S., Polyakov P.V., Yushkova O.V., and Sigov V.A. (2018) Spatial particle distribution during Stokes sedimentation of alumina in high temperature concentrated suspension-electrolyte for aluminium production, Tsvetnye Metally. 2018(2):45-50.

27. Yasinskiy A.S., Polyakov P.V., Voyshel Y.V., Gilmanshina T.R., Padamata S.K. (2018), Sedimentation behaviour of high-temperature concentrated colloidal suspension based on potassium cryolite, J. Dispersion Sci. \& Tech., 39:1492-1501.

28. Bakin K.B., Simakova O.N., Polyakov P.V., Mikhalev Yu.G., Simakov D.A., and Gusev A.O. (2011) Electroconductivity slurry-electrolyte of the molten system $\mathrm{NaF}-\mathrm{AlF}_{3}-\mathrm{CaF}_{2}-\mathrm{Al}_{2} \mathrm{O}_{3}, \mathrm{~J}$. Siberian Federal University. Engineering \& Technologies, 2011(4):162-169.

29. Kryukovsky V.A., Frolov A.V., Tkatcheva O.Yu., Redkin A.A., Zaikov Yu.P., Khokhlov V.A., and Apisarov A.P. (2006), Electrical conductivity of low melting cryolite melts, TMS Light Metals, 2006:409-413. 
30. Vaskova Z., Kontrik M., Mlynarikova J., and Boca M. (2015) Density of low-temperature $\mathrm{KF}-\mathrm{AlF}_{3}$ aluminium baths with $\mathrm{Al}_{2} \mathrm{O}_{3}$ and $\mathrm{AlPO}_{4}$ additives, Met. \& Mat. Trans. B, 46:485493.

31. Cassayre L., Palau P., Chamelot P., Massot L. (2010) Properties of low-temperature melting electrolytes for the aluminium electrolysis process: A review // J. Chem. Eng. Data, 55:45494560.

32. Silny A., Chrenkova M., Danek V., Vasiljev R., Nguyen D.K., and Thonstad J. (2004) Density, viscosity, surface tension, and interfacial tension in the systems $\mathrm{NaF}(\mathrm{KF})+\mathrm{AlF}_{3}, \mathrm{~J}$. Chem. Eng. Data, 49:1542-1545.

33. Padamata, S.K.; Yasinskiy, A.S., Polyakov, P.V. (2019) Electrolytes and its additives used in aluminium reduction cell: a review Metallurgical research \& technology, 116, (4): 410.

34. Thonstad J., Kisza A., and Hives J. (2006) Anode overvoltage on metallic inert anodes in lowmelting bath, TMS Light Metals, 2006:373-377.

35. Nekrasov V.N., Limanovskaya O.V., Suzdaltsev A.V., Khramov A.P., and Zaikov Yu.P. (2014) Stationary anodic process at platinum in $\mathrm{KF}-\mathrm{NaF}-\mathrm{AlF}_{3}-\mathrm{Al}_{2} \mathrm{O}_{3}$ melts, Rus. Met. (Metally), 2014(8):664-670.

36. Suzdaltsev A.V., Khramov A.P., Kovrov V.A., Limanovskaya O.V., Nekrasov V.N., and Zaikov Yu.P. (2016) Voltammetric and chronopotentiometric study of nonstationary processes at the oxygen-evolving anodes in $\mathrm{KF}-\mathrm{NaF}-\mathrm{AlF}_{3}-\mathrm{Al}_{2} \mathrm{O}_{3}$ melt, Mat. Sci. Forum, 844:19-26.

37. Padamata S.K., Yasinskiy A.S., and Polyakov P.V. (2018) Progress of inert anodes in aluminium industry: Review, J. Siberian Federal University. Chemistry, 2018(11):18-30.

38. Nekrasov V.N., Suzdaltsev A.V., Limanovskaya O.V., Khramov A.P., and Zaikov Yu.P. (2012) Theoretical and experimental study of anode process on carbon in $\mathrm{KF}-\mathrm{AlF}_{3}-\mathrm{Al}_{2} \mathrm{O}_{3}$ melts, Electrochimica Acta, 75:296-304.

39. Yasinskiy A.S., Padamata S.K., Polyakov P.V., and Vinogradov O.O. (2019) Anodic process on aluminium bronze in low-temperature cryolite-alumina melts and suspensions, Tsvetnye Metally, 2019(9):37-44.

40. Yasinskiy A.S., Padamata S.K., Polyakov P.V., Samoilo A.S., Suzdaltsev A.V., Nikolaev A.Yu. (2020) Electrochemical behaviour of $\mathrm{Cu}-\mathrm{Al}$ oxygen-evolving anodes in lowtemperature fluoride melts and suspensions, TMS Light metals, current issue.

41. Yasinskiy A.S., Vlasov A.A., Polyakov P.V., and Solopov I.V. (2016) Impact of alumina partial density on the process conditions of aluminium reduction from cryolite-alumina slurry parameters, Tsvetnye Metally, 2016(12):33-38.

42. Yasinskiy A.S., Polyakov P.V., and Klyuchantsev A.B. (2017) Motion dynamics of anodic gas in the cryolite melt-alumina high-temperature slurry, Rus. J. Non-Ferrous Metals, 58(2):109113.

43. Yasinskiy A.S., Polyakov P.V. (2016) Investigation of bubble behaviour at cryolite melt alumina slurry electrolysis, J. Siberian Federal University. Engineering \& Technologies, 9 (6): 854-871.

44. Nikolaev A.Yu., Suzdaltsev A.V., and Zaikov Yu.P. (2019) Cathode process in the KF-AlF $3-$ $\mathrm{Al}_{2} \mathrm{O}_{3}$ melts, J. Electrochem. Soc. (in press).

45. Nikolaev A.Yu., Suzdaltsev A.V., Polyakov P.V., and Zaikov Yu.P. (2017) Cathode process at the electrolysis of $\mathrm{KF}-\mathrm{AlF}_{3}-\mathrm{Al}_{2} \mathrm{O}_{3}$ melts and suspensions, J. Electrochem. Soc., 164(8):H5315-H5321.

46. Wei Zh., Peng J., Wang Y., Liu K., Di Yu., and Sun T. (2019) Cathodic process of aluminium deposition in $\mathrm{NaF}-\mathrm{AlF}_{3}-\mathrm{Al}_{2} \mathrm{O}_{3}$ melts with low cryolite ratio, Ionics, 25:1735-1745.

47. Yasinskiy A.S., Padamata S.K., Polyakov P.V., Varyukhin D.Yu. (2019) Electrochemical characterization of the liquid aluminium bipolar electrode for extraction of noble metals from spent catalysts, Non-Ferrous Metals, 2: in press.

48. Simakov D.A. (2006) Studying peculiarities of electrolysis of alumina suspensions in fluoride melts in purpose of improving the Hall-Heroult process [In Russ], dissertation...cand.sc. Krasnoyarsk. 